DOI: https://doi.org/10.32839/2304-5809/2021-11-99-40

УДК $37.01 ; 004.4$

Ніколаєнко Л.П., Василенко І.А., Бойко Я.М.,

Логвина О.В., Астапенко О.О., Українська К.В.

Комунальний заклад «Навчально-виховний комплекс «Загальноосвітній навчальний заклад I-II ступенів - академічний ліцей № 15» Кам'янської міської ради

\title{
ДОСЛІДЖЕННЯ ОБІЗНАНОСТІ ПЕДАГОГІЧНИХ ПРАЦІВНИКІВ ЗАКЛАДУ ЗАГАЛЬНОЇ СЕРЕДНЬОЇ ОСВІТИ У ПИТАННІ АКАДЕМІЧНОЇ ДОБРОЧЕСНОСТІ ТА ЗАХИСТУ АВТОРСТВА НАУКОВИХ І МЕТОДИЧНИХ РОЗРОБОК
}

\begin{abstract}
Анотація. У роботі висвітлена актуальність дотримання академічної доброчесності серед усіх учасників освітнього процесу закладів загальної середньої освіти під час дистанційного навчання та оформлення наукових, навчальних і методичних праць вчителів. Шляхом анкетування визначено обізнаність педагогічних працівників ліцею у питаннях аналізу текстів на унікальність за допомогою відомих програмних продуктів, оформлення охоронних документів та запобігання плагіату з підтриманням політики відкритого доступу при публікації власних робіт. Здійснено аналіз на плагіат навчально-методичної літератури, проаналізовано висновки програмної перевірки. За результатами анкетування та співбесід було сформовано план роботи по проведенню тренінгів щодо користування сервісами антиплагіату та вивчення принципів написання статей відповідно засадам академічної доброчесності, оформлення цитувань раніше опублікованих матеріалів, створення авторських методичних посібників з основних предметів, реєстрації охоронних документів; розробка і впровадження механізмів часткової або вибіркової перевірки робіт учнів з поясненням правил доброчесного виконання домашніх завдань.
\end{abstract}

Ключові слова: освіта, наука, плагіат, академічна доброчесність, патентування.

Nikolaienko Larysa, Vasylenko Inna, Boiko Yaroslava, Lohvyna Olha, Astapenko Oksana, Ukrainska Kateryna Educational complex «General education of I-II degrees academic lyceum №15»

\section{RESEARCH OF AWARENESS OF PEDAGOGICAL EMPLOYEES OF THE INSTITUTION OF GENERAL SECONDARY EDUCATION IN THE ISSUE OF ACADEMIC INTEGRITY AND PROTECTION OF AUTHORS}

Summary. The paper highlights the relevance of academic integrity among all participants in the educational process of general secondary education during distance learning and design of scientific, educational and methodological work of teachers. To a greater extent, the introduction of the principles of academic integrity in the educational process mainly concerns students, but teachers also work closely with various objects of copyright and must design their scientific and methodological developments accordingly. The questionnaire determined the awareness of pedagogical staff of the lyceum in the analysis of texts for uniqueness with the help of well-known software products, security documents and prevention of plagiarism while maintaining an open access policy when publishing their own works. None of the respondents consider the observance of academic integrity to be useless. But $8.1 \%$ are not willing to check their work for plagiarism, which may indicate uncertainty about the originality of the work or is regarded as additional work. Most teachers are familiar with plagiarism testing programs, but only $21.6 \%$ sometimes use them in their work. $16.2 \%$ are not familiar with such services. Now almost all publications are checked for uniqueness and the detection of plagiarism in the work submitted to the editors is a serious violation by the author. Therefore, conducting a selection to get acquainted with anti-plagiarism services is appropriate. $100 \%$ of authors agree to share their own work with colleagues, while $78.4 \%$ are in favor of preserving their authorship. But only $32.4 \%$ of teachers are familiar with the mechanisms of patenting, $64.9 \%$ are interested in this issue. The conclusion on the question: "Do you support the open access policy?" Is interesting. Again, the same $8.1 \%$ of respondents intend to hide their work, which allows us to conclude that plagiarism is present in the works, but we must set a goal to correct the situation and learn to create unique manuscripts. The analysis on plagiarism of educational and methodical literature is carried out, the conclusions of program check are analyzed. Based on the results of questionnaires and interviews, a work plan was formed to conduct trainings on the use of anti-plagiarism services and study the principles of writing articles in accordance with the principles of academic integrity, citations of previously published materials, creation of author's manuals on major subjects, registration of security documents; development and implementation of mechanisms for partial or selective examination of students' work with an explanation of the rules of honest homework.

Keywords: education, science, plagiarism, academic integrity, patenting.

$\Pi$ остановка проблеми. Дотримання правил академічної доброчесності є актуальним серед усіх учасників освітнього процесу. Найбільш гостро проблема списування (плагіату) серед учнів постала у період дистанційного навчання у зв'язку з послабленням контролю з боку вчителя над виконанням контрольних заходів та самостійних робіт. Педагогічні працівники мають зобов'язання в написанні наукових та методичних матеріалів, але не завжди дотримуються засад академічної доброчесності за браком часу, досвіду або інших причин. Отже, існуе необхідність у додатковому навчання, та розробці засобів контролю 
дотримання академічної доброчесності серед здобувачі освіти та педагогів.

Аналіз останніх досліджень і публікацій. Міжнародний центр академічної доброчесності визначає академічну доброчесність як дотримання п'яти фондаментальних цінностей: чесності, довіри, справедливості, поваги, відповідальності та відваги до дій. Стаття 42 Закону України «Про освіту» визначає академічну доброчесність як сукупність етичних принципів та визначених законом правил, якими мають керуватися учасники освітнього процесу під час навчання, викладання та провадження наукової (творчої) діяльності 3 метою забезпечення довіри до результатів навчання та/або наукових (творчих) досягнень. Порушенням академічної доброчесності вважається:

1. Академічний плагіат - оприлюднення результатів дослідження або частин тексту (рисунків, фротографрій, таблиць, креслень тощо) інших авторів як власних без цитування. Посилання на роботи інших авторів допускається лише із зазначенням їх авторства у бібліографрічному списку, при цьому частка таких фррагментів повинна складати не більше $30 \%$ загального тексту роботи (в окремих випадках, зазначених в умовах публікації - 20-25\%).

2. Самоплагіат - повторне публікування раніше опублікованих робіт як нового результату діяльності. Допускається посилання на свої попередні праці з доповненням їх новими матеріалами.

3. Фабрикація - вигадування даних, чи фрактів, що не $є$ результатом роботи автора.

4. Фальсифікація - зміна чи модифрікація вже наявних даних, що стосуються освітнього процесу чи наукових досліджень з присвоєнням результатів.

5. Списування - використання літературних чи інших джерел під час перевірки знань.

6. Обман. Наприклад, здавання іспитів чи інших контрольних заходів, підставними особами.

7. Хабарництво.

8. Необ'єктивне оцінювання.

9. Допомога учням під час оцінювання їх навчальних результатів чи створення перешкод під час оцінювання.

10. Вплив на працівника, щоб він здійснив необ'єктивне оцінювання (частина 4 статті 42 Закону України «Про освіту») [1].

До основних принципів академічної доброчесності відносять: старанність, самостійність у навчанні; відповідальність за власні вчинки і чесне здобуття оцінок; толерування думок інших, взаємоповага та підтримка; гідна та моральна поведінка під час навчального процесу та поза ним.

Наслідки тривалих та системних порушень академічної доброчесності:

- знецінення університетських дипломів у країні, невизнання їх за кордоном;

- випускникам університетів важко влаштуватися на хорошу роботу, бо роботодавці не довіряють системі вищої освіти та закладам вищої освіти;

- зниження якості медичного обслуговування;

- стагнація науки, знецінення наукового потенціалу держави;

- гальмування розвитку економіки;

- країна втрачає авторитет у світі.

Тому дотримання академічної доброчесності є важливим аспектом розвитку окремої особистості та країни вцілому, вона:
- забезпечує довіру до результатів навчання;

- передбачае здобуття власних знань і розвиток власних здібностей;

- забезпечує випускникам закладів загальної середньої освіти чесний вступ до університету, а потім - гарну роботу [2].

У січні 2021 року $100 \%$ педагогічних працівників НВК - академічний ліцей № 15 успішно завершили онлайн-курс «Академічна доброчесність» тривалістю 4 години та отримали навички формування культури академічної доброчесності. Курс надав можливість подивитися на дисципліни через призму академічної доброчесності та пропонував теоретичні основи і практичні інструменти, які допомагають посилити культуру академічної доброчесності.

Вивчаючи цей курс, педагогічні працівники дізналися теоретичні аспекти академічної доброчесності, ознайомилися з факторами, що безпосередньо впливають на культуру академічної доброчесності здобувачів освіти, навчилися застосовувати теоретичні знання на практиці у викладанні в умовах дистанційного освітнього процесцу у закладах середньої загальної освіти. Під час здійснення різноманітних анкетувань серед педагогічного складу ліцею, вчителям було запропоноване таке питанна: «Що Ви робите для того, щоб запобігати випадкам порушень академічної доброчесності серед здобувачів освіти (списування, плагіат, фральсифікація тощо)? Варіанти відповідей:

- знайомлю здобувачів освіти 3 основами авторського права;

- проводжу бесіди щодо дотримання академічної доброчесності;

- на уроках даю такі завдання, які унеможливлюють списування;

- використовую методичні розробки для dpopмування основ академічної доброчесності»

Опитування показало, що всі перелічені варіанти попередження списування (плагіату) реалізуються педагогами і успішно вирішують це питання.

Основним аспектом забезпечення академічної доброчесності під час дистанщійної форми навчання $€$ наявність увімкненої камери під час заняття онлайн та виконання практичних робіт, які унеможливлюють списування. Так, у листопаді 2021 року, відбувся перший відкритий онлайн-урок практичної роботи з трудового навчання від вчителя Астапенко О.О. Учениці 6-го класу ознайомилися 3 правилами техніки безпеки роботи на кухні та технологією харчового виробництва, виконали практичну роботу по приготуванню пиріжків разом зі вчителем у реальному часі.

Виділення невирішених раніше частин загальної проблеми. У більшій мірі впровадження засад академічної доброчесності в совітній процес переважно стосуеться здобувачів освіти, але педагоги теж тісно взаємодіють 3 різноманітними обектами авторського права та мають офрормлювати свої наукові та методичні розробки відповідним чином.

Формулювання цілей статті. Метою роботи є отримання інформації щодо обізнаності педагогічного колективу НВК - академічний ліцей № 15 у питанні забезпечення унікальності 
наукових публікацій та авторських методичних розробок, проведення вебінарів та інших заходів для отримання необхідного досвіду та знань 3 оформлення свідоцтв авторського права.

Виклад основного матеріалу дослідження. Для досягнення мети, в рамках науково-дослідної роботи, було розроблене тестування, що складалося 310 питань та було опрацьоване 100\% викладачів 1-11 класу. Результати опитування зведені у табл. 1.

3 табл. 1 можна зробити наступні висновки. Близько половини педагогів мають власні наукові публікації (за іншими даними публікації мають більшість учителів ліцею).

У січні 2021 року всі учителі ліцею пройшли курси «Академічна доброчесність». На сьогодні $\epsilon$ відсоток $(16,2 \%)$ нових співробітників, які проходять цей курс та 2,7\%, які потребують більш детальної інформації та направлення для підвищення кваліфікації 3 цього питання. Ніхто 3 опитаних не вважає дотримання академічної доброчесності марною справою. Але 8,1\% не налаштовані на перевірку своїх робіт на плагіат, що може вказувати на невпевненість в оригінальності роботи або розцінюеться як додаткова робота. Більшість педагогічного колективу $(62,2+21,6=83,8 \%)$ знайомі 3 програмами перевірки плагіату у текстах, але лише $21,6 \%$ інколи їх використовують у своїй роботі. 16,2\% взагалі не знайомі з такими сервісами. Зараз майже всі публікації перевіряються на унікальність і виявлення плагіату, рукопис повертається, якщо у наданій до редакції роботі є серйозні порушенням 3 боку автора.

100\% авторів згодні ділитися з колегами своїми власними наробками, при цьому 78,4\% виступають за збереження свого авторства. Але лише $32,4 \%$ учителів знайомі з механізмами патентування, 64,9\% зацікавилися цим питанням. Тому, необхідно більш детально вивчити механізми і правила патентування, правила користування та розповсюдження матеріалів згідно політики відкритого доступу. Цікавим є висновок з питання: «Чи підтримуєте Ви політику відкритого доступу?». Знову, ті самі 8,1\% опитаних мають на меті приховати свої роботи, що дозволяе зробити

Результати опитування педагогічного колективу НВК - академічний ліцей № 15

\begin{tabular}{|c|c|c|}
\hline $\begin{array}{l}\text { № } \\
\text { 3/ח }\end{array}$ & Питання & Результати опитування \\
\hline 1 & $\begin{array}{l}\text { Чи є Ви автором наукової публікації } \\
\text { або авторської методичної розробки? }\end{array}$ & $\begin{array}{l}-\mathrm{Ta \kappa}-51,4 \% \\
-\mathrm{Hi}-48,6 \% \\
\end{array}$ \\
\hline 2 & $\begin{array}{l}\text { Чи знайомі Ви з засадами } \\
\text { академічної доброчесності? }\end{array}$ & $\begin{array}{l}\text { - Так, відвідав семінар (вибінар, тренінг, курси) - 81,1\% } \\
\text { - Так, цікавлюся цим питанням та займаюся самоосвітою - 16,2\% } \\
\text { - Ні, але бажаю ознайомитися з цією інформаціею - } 2,7 \% \\
\text { - Ні, вважаю це не потрібним - 0\% } \\
\end{array}$ \\
\hline 3 & $\begin{array}{l}\text { Чи вважаєте Ви, що перевірка на } \\
\text { плагіат сприяе підвищенню якості } \\
\text { публікації/методичної розробки? }\end{array}$ & $\begin{array}{l}\text { - Так, унікальна розробка має високу цінність - 91,9\% } \\
\text { - Ні, це не потрібно - 8,1\% }\end{array}$ \\
\hline 4 & $\begin{array}{l}\text { Чи знайомі Ви з програмами } \\
\text { (онлайн-сервісами) перевірки } \\
\text { унікальності тексту? }\end{array}$ & $\begin{array}{l}\text { - Так, іноді користуюсь ними - } 21,6 \% \\
\text { - Так, але не доводилося користуватися - } 62,2 \% \\
\text { - Нi, марна витрата часу - } 0 \% \\
\text { - Нi, вперше чую про такі програми - } 16,2 \% \\
\end{array}$ \\
\hline 5 & $\begin{array}{l}\text { Які з перелічених програм (онлайн- } \\
\text { сервісів) перевірки унікальності } \\
\text { тексту Вам знайомі? (можна вибрати } \\
\text { кілька варіантів відповідей) }\end{array}$ & $\begin{array}{l}\text { - Advego Plagiatus - 18,9\% } \\
\text { - Etxt Antiplagiat - 10,8\% } \\
\text { - CONTENT-WATCH - 5,4\% } \\
\text { - UNPLAG - 21,6\% } \\
\text { - Text.ru - } 21,6 \% \\
\text { - StrikePlagiarism.com - 8,1\% } \\
\text { - Iншi - 8,1\% } \\
\text { - Взагалі не знайомий(ма) з такими програмами - 48,6\% }\end{array}$ \\
\hline 6 & $\begin{array}{l}\text { Чи перевіряєте Ви свої роботи на } \\
\text { унікальність перш ніж відправляєте } \\
\text { до публікації? }\end{array}$ & $\begin{array}{l}\text { - Так, це дозволяе виявити слабкі місця роботи - 43,2\% } \\
\text { - Ні, покладаю цю задачу на видавництво та буду виправляти, } \\
\text { якщо це необхідно - 56,8\% }\end{array}$ \\
\hline 7 & $\begin{array}{l}\text { Чи вважаєте Ви доцільною перевірку } \\
\text { робіт учнів на плагіат? }\end{array}$ & $\begin{array}{l}\text { - Так, більшість беруть готові роботи з Інтернету - 91,9\% } \\
\text { - Нi, це не потрібно - 8,1\% }\end{array}$ \\
\hline 8 & $\begin{array}{l}\text { Чи важливе для Вас збереження } \\
\text { авторства публікаціі/розробки? }\end{array}$ & $\begin{array}{l}\text { - Так, це результат моєї роботи, але цитування іншими авторами } \\
\text { допускаю, за умови оформлення бібліографрічного посилання і } \\
\text { розповсюдження на безкомерційній основі - 78,4\% } \\
\text { - Так, це моя робота, я не дозволяю нею користуватися - } 0 \% \\
\text { - Ні, всі можуть її використовувати і розповсюджувати на } \\
\text { безкомерційній основі - } 21,6 \% \\
\text { - Ні, всі можуть її використовувати на власний розсуд (видати за } \\
\text { свою, розповсюджувати на комерційній основі тощо) - } 0 \% \\
\end{array}$ \\
\hline 9 & $\begin{array}{l}\text { Чи знайомі Ви з процедурою } \\
\text { патентуванням власних розробок? }\end{array}$ & $\begin{array}{l}\text { - Так, маю патент на винахід/патент на корисну модель - 10,8\% } \\
\text { - Так, маю авторське свідоцтво - 0\% } \\
\text { - Так, але власних патентів/авторських свідоцтв не маю - } 21,6 \% \\
\text { - Ні, ніколи не цікавив цей напрям, але хочу дізнатися - } 64,9 \% \\
\text { - Ні, мені це не цікаво - 2,7\% } \\
\end{array}$ \\
\hline 10 & $\begin{array}{l}\text { Чи підтримуете Ви політику } \\
\text { відкритого доступу (розміщення } \\
\text { власних матеріалів у мережі } \\
\text { Інтернет зі збереженням авторства)? }\end{array}$ & $\begin{array}{l}\text { - Так, я можу оперативно отримувати нову інформацію про } \\
\text { розробки інших авторів, мої роботи можуть читати та цитувати } \\
\text { iнші автори - 91,9\% } \\
\text { - Ні, не вважаю за потрібне демонструвати свої розробки }-8,1 \%\end{array}$ \\
\hline
\end{tabular}


висновок про присутність плагіату в роботах, але треба поставити мету виправити ситуацію і навчитися створювати унікальні рукописи.

Значна кількість плагіату виявляеться і в учнівських роботах, брак часу та значні об'єми домашнього завдання є причиною пошуку швидких рішень - списування. 91,9\% учителів вважають доцільним перевірити учнівські роботи. Звичайно це займатиме багато часу i опрацювати подібним чином всі роботи не можливо. Тому, потребує впровадження механізм часткової або вибіркової перевірки робіт учнів з поясненням правил доброчесного виконання домашніх завдань. Але $8,1 \%$ вважають це не потрібним, скоріше за все, за браком часу розцінюючи це як додаткову робота.

Таким чином, слід звернути особливу увагу на перевірку унікальності текстів, що подаються до публікації педагогічними працівниками ліцею та висвітлити це питання на нарадах, на групових та індивідуальних консультаціях, запланувати проходження вебінарів та тренінгів.

Значним досвідом для учителів була перевірка на плагіат навчально-методичної літератури.

Рішенням Вченої ради Дніпровського державного технічного університету Міністерства освіти і науки України (протокол № 11 від 23 вересня 2021 року) рекомендований до друку навчальний посібник «Випереджаюча освіта для сталого розвитку" для здобувачів загальної середньої та вищої освіти I-III рівнів (автори: Василенко I.A., Ніколаєнко Л.П., Іванченко А.В., Гуляев В.М., Чупринов Є.В., Скиба М.I., Коваленко І.Л.) Обов'язковою умовою друку навчального посібника $є$ його перевірка на плагіат, що була здійснена за допомогою програми StrikePlagiarism. com. Ця програма забезпечуе перевірку академічних письмових робіт (підручники і посібники, дипломи, дисертації тощо), текст порівнюється 3 інтернет-ресурсами та базою даних системи.

Результати перевірки включають у себе виявлення подібностей тексту з відомими джерелами. Що надаються у вигляді активних посилань на джерело та подібність у відсотках. Аналіз результатів перевірки показав, що на 91,3\% даний посібник складається з власних матеріалів авторів, що відповідає вимогам, які пред'являються до навчальних посібників.

На наявність запозичень, за допомогою онлайн-сервісу Text.ru, був перевірений навчально-методичний посібник «Практикум 3 природознавства для 5-го класу» (автор: Василенко I.А.). Text.ru - найпопулярніший ресурс для перевірки у режимі онлайн, він виявляє неякісний рерайт та просте переставляння слів і фрраз місцями, здійснюе пошук по інтернет-ресурсам.

Результати перевірки показали 100\% унікальності тексту, що е високим результатом та вказуе на оригінальність і якість розробленого навчально-методичного посібника. Крім того, посібник надано до Державного підприємства «Український інститут інтелектуальної власності» для отримання свідоцтва «Авторське право на твір», про що $є$ позитивне рішення від 22 жовтня 2021 року.

Висновки 3 даного дослідження і перспективи. В план роботи освітнього закладу включено проведення тренінгів щодо користування сервісами антиплагіату та вивчення принципів написання статей відповідно засадам академічної доброчесності, офрормлення цитувань раніше опублікованих матеріалів, створення авторських методичних посібників з основних предметів, реєстрації охоронних документів. Запланована розробка і впровадження механізмів часткової або вибіркової перевірки робіт учнів з поясненням правил доброчесного виконання домашніх завдань.

\section{Список літератури:}

1. Освітній омбудсмен України. Академічна доброчесність залежить від усіх учасників освітнього процесу. URL: https://eo.gov.ua/akademichna-dobrochesnist-zalezhyt-vid-usikh-uchasnykiv-osvitnoho-protsesu/ (дата звернення: 04.11.2021).

2. Нова Українська школа. Академічна доброчесність - як їі пояснити учням і створити систему в школі. URL: https://nus.org.ua/articles/akademichna-dobrochesnist-yak-yiyi-poyasnyty-uchnyam-i-stvoryty-systemu-vshkoli/ (дата звернення: 04.11.2021).

\section{References:}

1. Osvitnij ombudsmen Ukrayiny. Akademichna dobrochesnist zalezhyt vid usix uchasnykiv osvitnogo procesu. Available at: https://eo.gov.ua/akademichna-dobrochesnist-zalezhyt-vid-usikh-uchasnykiv-osvitnoho-protsesu/ (accessed 04 November 2021).

2. Nova Ukrayinska shkola. Akademichna dobrochesnist - yak yiyi poyasnyty uchnyam i stvoryty systemu v shkoli. Available at: https://nus.org.ua/articles/akademichna-dobrochesnist-yak-yiyi-poyasnyty-uchnyam-i-stvorytysystemu-v-shkoli/ (accessed 04 November 2021). 